\title{
CONCEPTION OF ARTISTIC WORD AS A SIGN IN MODERN LITERARY STUDY
}

\section{Sventsitska E. M.}

\section{INTRODUCTION}

In the history of literature study the specifics of word was comprehended ranging from the Word that "was in the beginning" and to a set of symbols between two spaces. Word being basically a completelly concrete phenomenon, the essence of which is presumably crystal clear (each schoolboy knows literature is an art of word), in the real practical study of literature disintegrates into multicity of categories that cannot be summarized in one and that simultaneously is something united "literary work", "text”, “artistic word”, "poetic langiage”, "poetic speaking” etc. All this multiciplity, obviously, is the row od hypostasiss of single essence, that appears so universal and all-embracing that becomes hard to define. In such situation not even of the logo-centrism per say, but of expansion of the word phenomenon to complete boundlessness it is very difficult, but at the same time highly necessary to comprehend the specifics of the word.

In a comprehension of the word phenomenon in a study of literature there are two opposite tendencies: comprehension of word as sign and comprehension of it as an ontological meaningfulness. Polarity of these tendencies shows up very clearly. If a word is a sign, then it defines a certain meaning. A word than becomes a conditional construct. Thus, the word is an instrument, a mean, something inferior. If on the contrary a word is a special particular reality of existence, then it is a direct embodiment of a meaning. In this case word is not a mean, but a self-valuable spiritual essence. This essence is of an active and creative character.

The aim of this work is to analyse concepts of word belonging to the first of the above mentioned tendencies.

\section{Structural-linguistical poetics of V.P. Grigoriev and structural-semantical poetics of U.M. Lothman}

Comprehending word as to the sign becomes actual in the second half of XX of century. This concept appeares in the structural-linguistic poetics of Grigoriev and in the structural-semanthical and culturological poetics of U.M. Lothman. 
V.P. Grigoriev examines a poetic word as "certain form of language

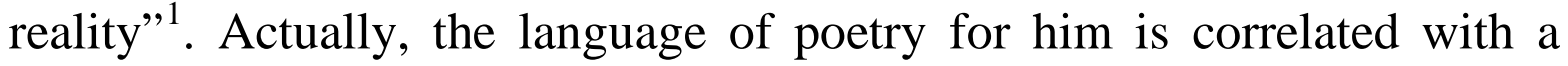
national language. A language of poetry is the "creative use of national language" ${ }^{\prime 2}$. This use envisages semantic transformations of linguistic word, unusual connections of words. Instrumental, official character of word in the comprehension of V.P. Grigoriev is well-proven to the limit. Thus, reflecting of nature of poetic word, he asserts: there is a word as instruments "On the first city. The thesis of Gymboldth gets substantial expansion and at the same time specification taking into account development of language as instruments of the vivid thinking”3 ${ }^{\text {. }}$

This conformity to law especially clearly shows up in conception of internal form of word and in conception of word as expressema: the "Internal form it is possible to define as totality of the artistic uses of certain unit of poetic language, historically variable and publicly meaningful great number of contexts of his consumption"4; "Word as typical expressema of poetic language shows a reference to the cultural and historical paradigm of contexts individual use of this word, meaningful for society in certain moment of his development" ${ }^{5}$. Internal form and expressema -concepts are practically identical here. Espressema differs in the greater degree of structuralness (exactly in connection with expressema of V.P. Grigoriev talks about the "structure of word"). Expressema is the model of functioning of word in different individual contexts. It is tints of value, that create these individual word usages. Speech goes exactly about transformations of sense of word in the process of connection with other words, but not about new quality of word, that arises up in the context of artistic unit. Very characteristically, that, building a structure of expressema "wind", the researcher examines a word out of artistic reality. To him fully sufficiently word-combination ("wind of century", "wind of inspiration"), at most sentence. From a rhythm, from motion of experiencing in lyric unit he practically disengages oneself fully. Expressema in interpretation of V.P. Grigoriev is the sign of poetic language infinite meanings that arise up at individual word usages. Especially it is visible at the analysis of concrete expressema: "the word "bird" finds out possibility to characterize the most various phenomena. Compare next contexts in the poetry of present

\footnotetext{
${ }^{1}$ Григорьев В.П. Поэтика слова. М.: Наука, 1979. С. 15.

2 Там само. С. 103.

3 там само. С. 142.

${ }^{4}$ Tам само. С. 114.

${ }^{5}$ Там само. С. 148.
} 
time: (as) "White bird of salvation" (V. Shefner), "Tragical bird of lie" (E. Vinokur) or "late birds of newspapers" (R. Rojdestvensky)" ${ }^{\text {. Here }}$ distance is obviously underlined between an initial word "bird" and final values. These values arise out of collision of him with other words. Expressema is multiplicity of designated, that sends to the row of creative individualities. It connects different creative personalities in the construction of only verbal model.

From here directly conception of art swims out as a secondary designing system U.M. Lothman. An aim of this system is an information, special family transfer communication. The value of artistic work arises up through his informative capacity. An informative capacity is expressed in поліструктурності. U.M. Lothman asserts that artistic text is perceived in correlation with all row of actual for a reader models of the world ${ }^{7}$. Therefore the afore-named internal of artistic work are determined him by "supreme”, secondary character. "Model”, a "structure" is central concepts in early U.M. Lothman. It is concentrated on semantic and communicative nature of art in general and arts of word in particular: "If a work of art communicates something to me, it serves a purpose of communication between a sender and recipient, then in it it is possible to distinguish: a 1) the message - what was passed; 2) the languages - certain community, an abstract system that predetermines the act of communication"8 ${ }^{\text {. }}$

In the process of functioning of culture of U.M. Lothman distinguishes two types to communication: "I-He" and "I-I". In the article "About two models of communication in the system of culture" he will postulate their opposition: the common elements of the model (the sender is replaced by an addressee) appear "In the system "I-He" variables, and permanent is a code and report. Reports and information are constant, the transmitter of information changes. In the system "I-I" the transmitter of information remains to the same, but report in the process of communication of переформулюється and acquires new sense. It takes place as a result of that an additional - second - code and initial report are entered ${ }^{9}$.

Quality of artistic value appears as a result of co-operation these two models: "Art arises up not in a number of texts of the system "I-He" or system "I-I". The above-mentioned uses the presence of both

\footnotetext{
${ }^{6}$ Григорьев В.П. Поэтика слова. М.: Наука, 1979. С. 201.

7 Лотман Ю.М. Внутри мыслящих миров. Москва: Языки русской культуры, 1996. С. 241.

${ }^{8}$ Там само. С. 22.

9 Лотман Ю.М. Избранные статьи: В 3т. Таллин: Александра, 1992, Т. 1. С. 77.
} 
communicative systems for the sake of oscillation in the field of structural tension between them. An aesthetic effect arises up in moment, when a code begins to be used as a report, and report as code, when text is commuted from one system of communication in other, keeping in consciousness the audiences of copulas with both" ${ }^{10}$.

Exactly this transient, dynamic state is the attribute of artistic value. Farther U.M. Lothman draws conclusion about difficult correlation of poetic word with the word of human language: "Following the laws of auto-communication - segmentation of text on rhythmic segments, to erection of words to the indexes - poetic text enters into a conflict with the laws of human language. But perception of it as text by a human language is a condition without that allows poetry to exist and perform the communicative duty. However, a complete victory of seeing the poetry as on a message of human language results in the losing $\mathrm{it}^{11}$.

As well as in a human language, a word is the sign of the passed information: "a word is a permanent for this language sign with the firmly fixed form attributive and certain semantic filling. Together with it a word consists of elements, also permanent that have a grammatical and lexical value" is certain ${ }^{12}$. In this determination a word is perceived as some hard and static construction. This construction consists of the so hardly fixed list of elements.

Especially clearly this structurally-operative approach to a word shows up then, when U.M. Lothman goes across from a language word to the word artistic. He considers that in the text written with a human language, we deal with certain units of value and methods of their combination. In artistic text of word are the signs of unknown meanings. This table of contents is constructed from their connections. In artistic text character of connections determines semantics of units. Thus the real text has an artistic ("supreme") and inartistic (language) value simultaneously. Thus these systems designed one on other. Each on a background other is perceived as a "appropriate breach of law" that is the condition of informative ${ }^{13}$.

The brought expression over is obviously correlated with opinion G.O.Vinocur: "Sense of literature-artistic work is a certain betweenness by the direct value of words that he is written with, and maintenance,

\footnotetext{
10 Лотман Ю.М. Внутри мыслящих миров. Москва: Языки русской культуры, 1996. С. 86.

${ }^{11}$ Там само. С. 87.

12 Лотман Ю.М. Избранные статьи: В 3т. Таллин: Александра, 1992, Т. 1. С. 229.

13 Там само. С. 251..
} 
theme of it" ${ }^{\text {14 }}$. But a difference is in that, after U.M. Lothman, maintenance of artistic text can be constructed from comparison of parallel rows of signs.

Actually, text - and inartistic, and artistic - shows in U.M. Lothman's interpretation exactly construction, mechanism. About the "mechanism of text", about text as a "intellectual device" he talks in the article "Text in text”: "Text is presented as a device made as a system of heterogeneous spaces, in the continuum of that circulates an initial message» ${ }^{\text {.15 }}$. Artistic text shows the only complicated construction, code not with one, but with two codes: "Text appears before us twice in cipher; first coded is the system of human language. However, this text - the recipient of information knows it - in cipher yet to some by another character. In aesthetic operating of text conditions previous knowledge is included about this double enciphering in ignorance (and more precisely, incomplete knowledge) about the used here secondary code. As a recipient of information does not know that in text that perceived them, matters, he "suspects" all elements on the richness of content. It costs to us to walk up to text as to artistic, and in principle any element of element... it can appear ${ }^{16}$. Thus, between text artistic and inartistic there is not a quality difference. Quality of aesthetic is deep-rooted not so much in coding, in a semantic complexity, as in the wild of perception of this text. Not perceived as text in that insignificant elements become meaningful. Here, undoubtedly, in U.M. Lothman arises up rollcall with formal school. However, for formalists on the first plan meaningfulness of construction is pulled out. And in U.M. Lothman's priority are exactly arising up due to the action of this construction semantic changes. They generate transformation of language word in a "complex asemantic message"17. Such report is produced increase coding of poetic text. But it fully from these codes does not swim out. New values carry individual character and are founded, again, in a perceiving subject: "So, considering the pattern of wallpapers or listening un-programmed music, we add the defined values" to the elements of these texts; A "reader hyper-structures the text, he is inclined to erect to the minimum a role casual in his structure" ${ }^{18}$. There is it because text for U.M.Lothman is not only the "a firm structure"19.

\footnotetext{
${ }^{14}$ Винокур Г.О. О языке художественной литературы. Москва: Высшая школа,1991. С. 53

15 Лотман Ю.М. Избранные статьи: В 3тт. Таллин: Александра, 1992, Т. 1. С. 151.

16 Там само.С. 204.

${ }^{17}$ Там само. С. 83.

18 Лотман Ю.М. Внутри мыслящих миров. Москва: Языки русской культуры, 1996. С. 112.

19 Там само. С. 112.
} 
The text has "a stock on internal structural indefiniteness"20. Not all in him is determined by a construction. Exactly this feature of text provides a basis for dialogic relationships with a perceiving subject. However it is a dialogue a bit other plan, than in M.M. Bahtin. It has an above-subject character, co-operate here not different voices, but different codes: "Text behaves as an interlocutor in a dialogue: he reforms according to sample audiences. And an addressee answers him the same - uses the informative flexibility for alteration that approaches him to the world of text"21.

From one side, here obviously there is accenting of meaningfulness of perception in determination of phenomenon of artistic value. On the other hand, the special nature of word poetic becomes firmly established on a background a word a language. About possibilities of the different going near such sort of comparison of U.M. Lothman talks "Three functions of text" in the article. He writes, that from the point of view of information there is a language as system of passing of messages. Then the language of literature appears as an original and in a great deal strange corner of this system. She, from this point of view, shows only human language with additional limitations, with diminished informatively by a capacity. But, after U.M. Lothman, another view is possible. If to examine a creative function as an universal sign of language, then the language of literature appears as the most adequate embodiment of language as such. Then opposite semiotic models will appear an only limit sphere language space ${ }^{22}$.

Thus, at "informative" approach a language as system of information transfer sets to unit, an artistic word appears the separate case of such transmission. At approach "creative", opposite, the language of poetry sets to the point of counting out, a language becomes a case out of literature, in that it the aesthetic beginning exists only on the second plan. In U.M. Lothman, obviously, these oppositions correlate. Artistic word here not separate case language, but also language word not separate case of word artistic. First of all, the special nature of word artistic shows up in his aspiring to integration, to creation of value unit: "separate words are not only "moved" in a semantic relation (any word in artistic text is a trope) but also meet, their senses are integrated. There is that, relatively to poetic text, Tinianov named crowd "conditions poetic row" 23 .

\footnotetext{
20 Лотман Ю.М. Внутри мыслящих миров. Москва: Языки русской культуры, 1996. С. 113.

${ }^{21}$ Там само. С. 113.

22 Там само. С. 20.

23 Там само. С. 65.
} 
Will pay attention, that similar sort of statement it arose up not only U.M. Tinianov, but also in G.O. Vinokur: "In an artistic language any connection of words in a tendency grows into close, on phraseology unity, on something permanent, but not casual” ${ }^{\text {,2 }}$. Thus G.O. Vinokur underlines the special nature of poetic word. Such word-combinations "create new character, id est new poetic sense”, 25 .

In addition, U.M. Lothman connects two described higher approaches. He determines originality of development of poetic text as simultaneity of process of information transfer and creation of language, for understanding this necessary information : "At difficult operations a meanings creation language is inseparable from maintenance that expressed by it. In this last case we have already not only a report but also report a language about a language, report in that interest passes to his language" "26; "any innovative artistic work is a generic work by an unknown to the audience language that yet must be reconstructed and mastered by addressees" ${ }^{\prime 2}$. Thus, poetic word, not stopping to be the word of language and transmitter of information, simultaneously translated in other quality. It becomes the element of new unique language inseparable from this report.

Realization of sign nature of poetic word is in U.M. Lothman by the condition of adequate perception of text: "Sign nature of artistic text is ambivalent in the basis: from one side, text presents from itself reality, pretends to be, that has independent existence independent of author, by a thing among the things of the real world, on the other hand, he reminds constantly, that he is somebody's creation and means something"28. This duality of nature of text (reality that finds out the sign character) generates duality of sign. For U.M. Lothman, artistic work shows a mutual projection of signs convention, that peculiar "unconditionality of connection of plans of expression and maintenance", and signs iconic: the "Iconic signs the conditionalities of connection built on principle between expression and maintenance. Therefore, differentiation of plans of expression and maintenance in general labored. A sign designs its meaning,"29.

On the face of it, an iconic sign also looks as a construction. This construction sets the relation of analogy between designated and означаючим. About this conformity to law, in particular, speech goes to

\footnotetext{
${ }^{24}$ Винокур Г.О. О языке художественной литературы. Москва: Высшая школа,1991. С. 58.

${ }^{25}$ там само. С. 57.

26 Лотман Ю.М. Внутри мыслящих миров. Москва: Языки русской культуры, 1996. С. 18.

${ }^{27}$ Там само. С. 18.

28 Лотман Ю.М. Избранные статьи: В 3тт. Таллин: Александра, 1992, Т. 1. С. 138.

${ }^{29}$ там само. С. 31.
} 
the work of I.V. Cherednichenko "Semiotic method of Tartu school": "General linguistic diagramatism will be realized in the relations of connection between mark and to denotations of expression, that, though demonstrate additional copulas as a result of this similarity, the no less exist separately"30. So an iconic sign, as well as a sign is convention, assumes certain distance between mark and by denotation. Their conditional, structural similarity does not take off this distance.

Between that in U.M. Lothman signs convention and iconic nevertheless different nature. They are contrasted on the signs of discreteness/of continuality, semantic definiteness/of vagueness. But the most important their difference evidently, when U.M. Lothman calls to concrete text. Yes, in the article "Text in the process of motion: author-audience, intention-text”, commenting the verse of G.R. Derjavin, U.M. Lothman talks that voice organization of text", creates iconic character of the organ sounding that calms down, and faint sound of echo, and also and subjective visual associations"31. Not by chance U.M. Lothman in general such meticulous in the analysis of phonetic organization of poetic work. Obviously, exactly a voice side of poetic word is here the moment of combination mark and denotation. Therefore an iconic sign is not only an image but also expression of maintenance, thus from this concrete maintenance inseparable.

If these types of signs were one nature, then between them hardly relations could come true simultaneously and comparison, and nonsimilarity. But exactly they in U.M. Lothman is basis of generation of artistic text: "Text as though is doubled: he remains the rows of the graphicly expressed words and, at the same time, realized in certain iconic space. Sense of him is also doubled between these semantic spheres. But language and iconic signs are located in mutually not to the end of corresponding spaces. Thus, here it arises up and to incomplete determination accordance that creates terms for an increase of the meaning"32.

Exactly this incomplete adequacy of two sign systems that will be realized in text gives an opportunity to exist as though in an interval to him. Text is simultaneously the system of signs, and specific reality. In fact, from one side, as evidently from the already brought expression over of U.M. Lothman, "text presents from itself reality", and "reminds here, that he is somebody's creation and something means. But on the

\footnotetext{
30 Чередниченко И.В. Структурно - семиотический метод тартуской школы. Санкт-Петербург: Золотой век, 2001. С. 125-126.

31 Лотман Ю.М. Внутри мыслящих миров. Москва: Языки русской культуры, 1996. С. 97.

32 Там само. С. 97.
} 
other hand, in him a sign is overcame. U.M. Lothman asserts that in literature convention of relations of verbal manner and matter looks more evident. This fact confesses. And further efforts are sent to his overcoming, id est literature however connects maintenance and expression in "difficult formation of higher level of organization"33.

From here, that a poetic word shows the original field of tension and motion between a sign convention and iconic. It simultaneously and serves for the transmission of some maintenance and is his expression. It should be noted that such situation is in general characteristic for approach of U.M. Lothman. He maximally makes clear existent oppositions and finds out the methods of their co-operation. U.M. Lothman essentially, takes the tendency of separateness of word and world to the limit. But, maximally deepening in sign nature of word, he overcomes this separateness.

\section{Artistic word as dynamic event of meaning creation (G. Genette, R. Barth)}

Actually, the semiotic going near a word will postulate interpretation of text as a semantic structure. This structure carries immanent character. A word in this structure shows the dynamic event of determination. These tendencies show up in-process French structuralism G.Genette "Fiction and composition".

A main question that decides researcher in the work is a question about the specific of poetic expression (under expression G. Genette understands a "language act" out of any attachment to the subject). He decides a question about what expression such differs from an ordinary language report: "Thus, we, as well as most researchers of poetics, beginning from Aristotle, will appeal here to that divergence, that, doing a "language report work of art", allows to mark off him not from other works of art, but from "other types of language" - or linguistic - conduct”34.

In the comprehension of poetic expression G.Genette distinguishes two aspects: essencial and conditional. The first from them characterizes essence of this phenomenon, second are terms at that he becomes such. Characterizing the specific of poetic expression, G.Genette determines it from two parties - from semantic and formal.

\footnotetext{
33 Лотман Ю.М. Внутри мыслящих миров. Москва: Языки русской культуры, 1996. С. 73.

34 Женетт Ж. Вымысел и слог: fictio el dictio / Пер с фр. И. Стаф // Женетт Ж.Фигуры: В 2 т. Москва: Издательство им. Сабашниковых, 2003, Т. 2. С. 346.
} 
Right behind Aristotle, he respects him the semantic feature of poetic expression invented, fictional character. A scientist considers that being in the sphere of functionality provides for and exit outside the usual use a language. This sphere needs, foremost, authenticity. Fictionality of expression is neither truth nor lie, or is and truth, and lie simultaneously. He can be described only as "possible", after the word of Aristotle. G.Genette marks, that an author and recipient enter into inter a contract about mutual irresponsibility, that is expression of "aesthetic non-interest"35.

Thus, poetic expression in principle is not correlated with vital reality. It presents, as it writes G.Genette elsewhere, "invented universum"36, world that exists only in imagination of author and recipient. In a number of examples G. Genette exposes convention character of aesthetic reality. An author writes, that behavior of author of device looks like the word of "fiat demiurge and onomaturg". His action envisages the more or less implicit agreement of public. A reader voluntarily renounces the rights on a denial. This convention allows to the author, not applying explicitly to the addressee to acknowledge existing the invented objects. Thus, a "condition precedent that is considered executed consists in that he simply has this right to do this..."37.

In this formulation especially clearly evidently, as an accent is carried from expression, from text, on that is after text, are mutual relations of author and reader. Text belongs obviously in inferior position, examined only as a method of setting of these relations.

But, on the other hand, there is another side of specific of poetic expression - formal. She shows a "change in the use of human language, that understands already not as means of communication, transparent and neutral, but as the independent and not indifferent to replacement material" perceptibly perceived ${ }^{38}$.

This expression obviously calls with determination Jacobson (A "poetry is a language in her aesthetic function”). It marks first of all interpenetration of language and individual authorial attitude. The result of this interpenetration and transformation is - exactly this phenomenon of G. Genette names composition, style, by "existence of text": "composition, whatever mode he existed in, can be certain through

35 Женетт Ж. Вымысел и слог: fictio el dictio / Пер с фр. И. Стаф // Женетт Ж.Фигуры: В 2 т. Москва: Издательство им. Сабашниковых, 2003, Т. 2. С. 351.

${ }^{36}$ Там само. С. 374.

37 Там само. С. 375.

${ }^{38}$ Там само. C. 354. 
existence of text, different from his "conversation", though it is indissolubly constrained" with him; "Style is a minimum measure of literariness. However in itself this minimum of literariness, what problematic were not him aesthetic advantages, from the material point of view is undestroyed, as consists in existence to text inseparable, but however different from its pronouncing"39.

In this logic, naturally, the conditionality aspect of poetics appears more meaningful, what existential. Style in G.Genette from it is fully related to conditionality ${ }^{40}$. In formulation of this aspect G.Genette renounces the valued description of artistic expression. He asserts qualificatory essence of intention and perception in the wild aesthetic (perception, at that greater attention is spared to the form, than maintenance) : the "Worst picture, most unsuccessful sonata, most bad sonnet belong the no less to painting, music and poetries simply because by nothing other they can" not be ${ }^{41}$; "Novel is not necessities to be "well written", if to belong to literature good or bad : to it for this purpose it is enough to be a novel, thus by a device, that by itself a merit is small, exactly so as it is enough to answer a poem to the criteria (historically and in a civilized manner variable) of poetic composition”42 .

In principle, here already speech goes not about literature as art of word, but about literariness as about quality all, that it is written with words not for the sake of information. G.Gennet considers that literariness is the phenomenon plural.

Accordingly, it needs creation of pluralism theory. It is needed, that this theory comprehended the different methods of overcoming the language of her practical function. Thus there is possibility of creation of texts belonging to aesthetic perception and aesthetic estimation ${ }^{43}$.

Literariness, thus, is the phenomenon fully and fully dependency upon intention and perception. It is created fictionally and perceived in the same modality. It is created with intention of individual "transformation of human language" and as such transformation is perceived. A question about expression, about those mechanisms and structures that create this analogicalness of presentation for two different subjects, remains open.

In R. Bart's works word as such is not a central problem. By a considerably anymore measure he is interested by the problem of text and

39 Женетт Ж. Вымысел и слог: fictio el dictio / Пер с фр. И. Стаф // Женетт Ж.Фигуры: В 2 т. Москва: Издательство им. Сабашниковых, 2003, Т. 2. С. 446.

${ }^{40}$ Там само. С. 448.

${ }^{41}$ Там само. С. 359.

42 там само. С. 449.

43 Там само. С. 360. 
his structure - in a structural period, and problem of restructuring of this structure - in a period post-structural. It is however possible to say, that understanding of word definitely will organize the evolution of looks French researcher.

R. Bart, as well as U.M. Lothman, will proceed from the separateness of word and world. However understanding of word, expounded inprocess "Critic and truth", that for a structural period is programmatic, obviously carries in itself tracks of duality : "During great while classic bourgeois society saw in a word an or instrument, or decoration, presently we see a sign and embodiment of truth" ${ }^{44}$. Thus a word simultaneously and sends to some maintenance, and incarnates him in itself. In brackets will mark that such the duality being in works of U.M. Lothman, when speech goes about correlation of iconic and convention signs. However in U.M. Lothman these two beginning are in an equilibrium. Therefore he understands a word as relation and as some separateness, that mutually counterbalance each other.

R. Bart in a structural period perceives a word as autonomous reality. In connection with it in-process "Critic and truth" he is concentrated on the problem of the name, name : "Literature is a method of mastering of the name : all from a few sounds that fold the word of Germanti, Proust was able to cause the entire world to life. At heart a writer always believes that signs are not arbitrary and that name inherent to every thing from the nature..." 45 . Actually, the world existing in a word is created exactly by means of his ambivalent nature: "Every reader . knows about it: really he does not feel the involvement to some out-of-limit (it is distinguished by an author - E.S.) in relation to text world, so, as though the primary language of work grows in him other new words and teaches to speak in secondary language" 46 .

Similar statements are, again, and in U.M. Lothman (a poetic word is a "report in that interest is displaced into his language", work on an unknown audience to the language" ${ }^{\text {47 }}$ ). However in Bart a secondary language is correlated with creation of the separate world, creation of language it is synchronized with this process.

Therefore a poetic word becomes a word about a language and through him - about the world ("In fact to write - already means

${ }^{44}$ Барт Р. Критика и истина // Зарубежная эстетика и теория литературы XIX - XX веков. Москва: Издательство МГУ, 1987. С. 369.

${ }^{45}$ Там же. С. 371.

${ }^{46}$ Там же. С. 371.

47 Лотман Ю.М. Внутри мыслящих миров. Москва: Языки русской культуры, 1996. С. 18. 
definitely to organize the world, already means to think of him (to know some language - means to know, as people think this language” ${ }^{\text {} 4}$ ). Actually, by a prominent for literature moment in Bart and there is a reflection above a word and language : "Writer it is impossible to define in social role-play categories and by means of concept of prestige, it can be done only through that realization of word, he owns that. Writer - it and man before that a language appears as a problem, that, who feels all depth of language, and quite not him instrumentality and beauty"49.

The "depth of language", after by R. Bart, is determined her by symbolic nature. It is determined by a initiality polisemanticy that is concentrated in the word of literary work. R. Bart asserts that such polisemanticy can be comprehended in categories to the code. A symbolic language literary work talks that is exactly a language ambiguous. It is a language the code of that is arranged so that any descendant by him work has plural sense ${ }^{50}$. A word has plural maintenance and in a practical language, however their maintenance of expression clears up a situation context. In literary work all differently. As an author writes, that any, even to wide by the size work, "some prophetic brevity" is inherent. The point is that work consists of words corresponding to the primary code. At the same time he has other senses potentially. Initially these words were said pose be what context, except discipling on a polisemanticy. Therefore "situation there is work in that, - it always prophetic situation"51.

Lets pay attention, that in all these moments of logician R. Bart crosses paradoxical character with logic of the Russian religious philosophers. They determined a word what the name is also, asserted symbolic nature of word and language. The following is here obvious, however symbol as large as life connection between different realities grows into the special type of sign. Symbolizing becomes the method of code, organization of plan of expression, after that, is uncertainty. In this connection very characteristically, that word in Bart multiple-valued initially. Some only maintenance, logic of symbols, is not even envisaged in him - "empty forms" 52 . In an artistic word it is stopped up nothing, except the endless process of development of meanings: "There are a few senses in work. In actual fact, any epoch can imagine, as though owns canonical sense of work, it is however enough to widen the limits

48 Барт Р. Критика и истина // Зарубежная эстетика и теория литературы XIX - XX веков. Москва: Издательство МГУ, 1987. С. 361.

${ }^{49}$ Там же. С. 368.

50 Там же. С. 372.

51 Там же. С. 372.

52 Там же. С. 375. 
of history, that this only sense grew into plural, and the closed work - in

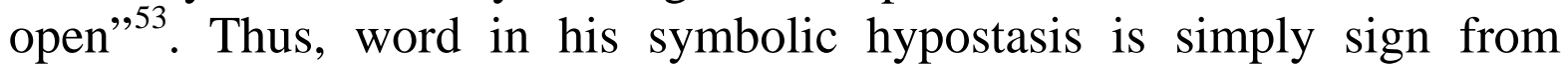
infinity mark without any dominant among them. In the process of the historical development this structure is filled new meanings, practically unconnected with each other: "work is "eternal" not because he imposes some only sense to the people, but because presents various senses to the only man that always, in different epochs one speaks and the same symbolically by a language: work offers, a man chooses" ${ }^{54}$.

On the other hand, this multiplicity nevertheless here yet means the complete breaking up. In it some possibility of unity is envisaged: "Intellect begins to become familiar with to new logic, he enters into the known area of "internal experience", the same truth that combines a poetic, romantic and discursive word sets out in searches itself, because from now on she is truth of word as such" ${ }^{\text {}}$. Actually, exactly this predictable, not hierarchical truth that appears in a word does a word really symbolic. It creates grounds at least for associating of multiplicity of meanings, about that speech went before.

In the same time value unity is felt by Bart so unstable and indefinite, that can not be incarnate in some rational or emotional given. She in general can not be something concrete, that is why fully passes to the word as continuous fluidity, as endless development. Only this value unity, obviously, can be present not phenomenally but energetically”.

Thus, there are two sides of richness of content of word - dismembering multiplicity and power only maintenance. They are answered by one in two formal expressed of word as reading and limning. Very characteristically, that these categories are through in works R. Bart. They are subject here to the comprehension not only as forms of organization and perception of word. They characterize first of all activity his aspect.

Limning, after by R. Bart, will realize in itself multiplicity of meanings. It self on itself, as activity, assumes dismembering distance, look to the word from one side. Reading envisages overcoming of distance, immersion in text. Exactly after his help only and it is possible to feel piercing him value unity: to "Write - means in certain sense to dismember the world (or book), and then fold again" ${ }^{\text {"56; }}$ "However only reading feels sense of love to work, supports passionate

53 Барт Р. Критика и истина // Зарубежная эстетика и теория литературы XIX - XX веков. Москва: Издательство МГУ, 1987. С. 370.

${ }^{54}$ Там же. 1987, С. 371.

55 Там же. С. 369.

${ }^{56}$ Там же. С. 385. 
relations with him. To read - means to wish work, to wish to grow into him, it means to yield up any the attempts to double work any other language, except the language of work" ${ }^{27}$.

The self-reading causes to life perception of work as a separate language. This language cannot be erected to none other. The only maintenance perceived in fact in the process of reading, as Bart writes a bit higher, "arises up as though for other side of language code" 58 . Actually, here arises a problematization of languages as such (and national, and "sociolect"). Problematized language as a system of signs, in that betweenness every mark and denotation is clearly certain. In duality of reading and limning self this definiteness yields to the deep doubt. In fact limning, as a matter of fact, there is a process of unforeseen meanings creation, reading is twinkling of deep unity. As a result the system of language is restored to a state of disbalance. For this reason "work... grows into a question that is set to the language, whose depth we aim проміряти, and to define limits. As a result work appears the method of грандиозного, endless inquiring about the word" 59 .

In the work "Introduction in structural analysis of narrative texts" a word is a sign, element of the code. Interest of researcher is concentrated on the problem of structure. It is the unifying and universal beginning. It exists out of the individual filling and implementation. A concept "work" and "text" in this work are used as synonymous, because work and text have a certain structure: "Text has a structure, what inherent and to any other texts and that yields to the analysis. Where does follow to search the structure of narrative texts? In texts, usually" ${ }^{\circ}$.

Thus, a structure carries immanent to text character, the elements of structure are signs and relations between them.

How does the structure of narrative text look? First of all, she contains three levels of description, between that the relations of successive integration are set: level of functions, level of actions and actually level of story. Functions and actions characterize the eventful side of work. They show a with a "plot elements" that mark development of events in time.

Most essential, formative exactly literary specific of text there is the third level: "a narrative level is created by the signs of narratives, totality

${ }^{57}$ Барт Р. Критика и истина // Зарубежная эстетика и теория литературы XIX - XX веков. Москва: Издательство МГУ, 1987. С. 386.

${ }^{58}$ Там же. С. 386.

${ }^{59}$ Там же. С. 373.

${ }^{60}$ Барт Р. Введение в структурный анализ повествовательных текстов // Зарубежная эстетика и теория литературы XIX - XX веков. Москва: Издательство МГУ, 1987. С. 388-389. 
of operators, that allow to the reintegrate function and action within the framework of narrative communication, that links a sender and recipient of the text" ${ }^{\prime \prime 1}$.

Creation of text is examined here as an act of communication. A narrating level will realize her dynamics. Units of this level distributive (correlates) and attributive (signs) - carry the mediated character. They are formed on crossing between events about that told in work, and eventfulness of the large world, as a result the structure of narrative text acquires ambivalent nature: "He (narrative level) destroys text in the outer world - there, where text opens (consumed) up; however in the same the time this level... gives to text completeness" ${ }^{\prime 2}$.

How does this sullenly-broken a secret structure work? R. Bart talks about it so: “... any story appears as a sequence of elements that is directly or mediated related to each other, that at the same time accumulate mutually; the mechanism of дистаксіi will organize the "horizontal" reading, and the mechanism of integration complements him to the "vertical" reading, unceasingly playing various potential possibilities, structure as though "nakulgae" and depending on realization of these possibilities gives to the story of her specific "tone", her energy, every unit appears both in the linear and in the deep measuring, and a story moves as follows: due to co-operation of two indicated mechanisms a structure branches, broadens, comes apart, and then again latchable on; appearance of any new element in it is good time envisaged by this structure" ${ }^{63}$.

Already in this fragment a structure at the beginning is described as something though movable, but system, with the levels, elements, relations. But in future she becomes not simply dynamic, but pulsating (and here yet and reminds post-modernism топос різоми). It appears at the end of work, that narrative text shows a "form, that won over principle of repetition and set the model of existence that is in becoming" 64 .

It formulation, in structural logic, appears to contradictions. On one side is a "model", construction, on other is "existence, that is in becoming" that any constructions are close. Thus, structuring the process, as though from within brought a researcher to understanding of the state of culturelessness. This state arises up then, when a structure begins to move, begins to work.

${ }^{61}$ Барт Р. Введение в структурный анализ повествовательных текстов // Зарубежная эстетика и теория литературы ХІХ - ХХ веков. Москва: Издательство МГУ, 1987. С. 416.

${ }^{62}$ Там же. С. 416.

${ }^{63}$ Там же. С. 420.

${ }^{64}$ Там же. С. 422. 
R. Bart's transition from structuralism to post-structuralism is related to the change of interests of scientist from work on text. Thus the analysis of structure changes on a text analysis. In this analysis text shows exactly plural reality in the state of becoming, with a problematization structure that comes apart outside. The productivity of this breaking of structure of text is demonstrated in-process the "Text analysis of one short story of E. Po".

Foremost, absence only mark, what peculiar to work, results in understanding of text as "process of determination". Lexie, text is dissembled on that, show "text denotations", and the arbitrariness of such segmentation Bart explains that "we must be satisfied with segmentation of denotation, not leaning on the segmentation hidden after him mark" ${ }^{\text {. }}$ Thus, it marks, certainly, it exists, but it, as about it already speech went to previous works, it is not given initially and not only. It only arises up in the process of reading-limning, thus in fundamental multiplicity and variate.

Mark is created by connotations of lexie. They show work of text on a limit with vital reality and with the inner world of perceiving subject : "These connotative senses can have a form of associations (for example, description of appearance of personage, that occupies a few phrases, can have one connotative marks only, is "nervousness" of this personage, although self-word "nervousness" and does not appear denotative in a plan); they can also appear in the form of relations, when a certain betweenness is set by two places of text, sometimes very remote one from another"66. Will pay attention, that the types of connotations distinguished in this fragment are correlated, firstly, with the process of distribution (setting of relations is between the elements of one level in the structure of narrative text - "relations"), and secondly, with attributive, fixative "signs" units of level there are stories about that speech went to "Introduction in structural analysis of narrative texts". Indeed, there is the taken off hierarchy in this work, here appear not levels, but layers. Multiplicity of elements of structure (functions, units), that are immanent, is replaced by multiplicity of codes. Codes is such elements of structure, that in direct sense and portable inlay some internal maintenance in external reality. In this work appear social, symbolic, ethnic, наративний and many other codes.

Multiplicity of codes is answered by multiplicity of hypostasiss of subject : "1) "I" is retell, artist an aim of that is an achievement of artistic effect, this "I” answers fully certain “you”: “you” are a reader;

\footnotetext{
${ }^{65}$ Барт Р. Избранные работы. Семиотика и поэтика. Москва: Прогресс, 1989. С. 426.

${ }^{66}$ Там же. С. 427.
} 
2) "I" eyewitness that can witness results scientific literature; 3) "I" participant of the event, an experimentator which will hypnotize Voldemar. In this case "you" is Voldemar himself 67 .

Actually, in this work before us are problematization of structures. The enormous amount of "structural" - codes, connotations, subjects restores text to a state of mobility. The process of birth of maintenance and dispersion of him is here fixed in vital reality, in the world of other texts.

Will pay attention, that here text, showing difficult formation, essentially, already stops to be a stable structure. And, in principle, it fully organically: in fact than more difficult structure, than any more in her elements, levels, relations between them - that she is recreated less. Clearness, clarity, centrality all these internals of structure with her complication become problematic. So, a structure disappears in structure, as treasure goes under earth. Bart perfectly sees this conformity to law and consciously uses her. Complicating and breaking a secret the structure of text, he converts her into a "network" that catches fluidity of being.

\section{CONCLUSIONS}

Thus, R.Bart perceives an artistic word ambivalently: in sign of and embodiment of truth". An equilibrium between these two interpretations is problematic, that is why in a structural period, speaking about a word as about the name, as about voice meaningfulness, R. Bart will postulate a word as special reality, that concentrates in itself essence of language and endlessness of maintenance that is in the state of becoming. Farther, as far as the change of interest from work on text, from структурування on anti-structurality, a word becomes a sign from безліччю indefinite and transitional in each other mark, by the element of process of meaning creation.

Thus, we found out, that after all the varieties of going near an artistic word as to the sign it is here possible to see the row of general lines. Because of inalienable from this approach of postulation of conditional connection between mark and an accent is displaced denotations from a word (and through that - from work, text) on a perceiving subject. In conception of literariness of G. Genette ("fictionality" in creation and perception of work), in the comprehension of "text as pleasure", "text as pleasure” in Bart this conformity to law shows up clearer in all. A word (and language, and artistic) becomes the dynamic event of determination (expressema of V.P. Grigoriev, double code of U.M. Lothman, triune

\footnotetext{
${ }^{67}$ Барт Р. Избранные работы. Семиотика и поэтика. Москва: Прогресс, 1989. С. 437.
} 
process of denotation, conotation and exemplification of G. Genette, denitation and conotation of lexia in Bart). Quality of artistic value contacts with imposition on the that method of co-operation, what peculiar to the signs of pragmatic language, new, authorial method of their cooperation (of "transformation of lexeme” of V.V. Vinogradov, “деавтоматизація of everyday language" of U.M. Lothman, "movement" of G. Genette, “integration” of Bart.

\section{SUMMARY}

The work is dedicated to the problem of artistic word - one of the principal and most important problems of the modern literary theory. The author describes, systematizes and analyses the concept of artistic word as a sign in the modern literary theory, based upon the works of V.P. Grigoriev, U.M. Lothman, G. Genette, R. Bart. Namely, the notion of "expressema" in the understanding of V.P.Grigoriev is analyzed, and is defined that the sign of poetic language with infinity of defining notions, which arise in individual words utilization. It is defined that this very source of structural-semiotic poetics of U.M. Lothman where the understanding of the word is rooted not only in its' double coding, semiotic complication, but also in the nature of perception, when the nonsignificant elements of the text become significant. This shift towards perception becomes more notable in the concept of literacy of G. Genette, which in his work "Invention and composition" becomes a phenomenon, completely dependent of the intention and perception; it is created with the functionality and perceived in the same modality; it is created with the intention of individual "transformation of the natural language" and perceived as such transformation. The work also defined that the passing from structuralism to post-structuralism of $\mathrm{R}$. Bart relates to the shift of interest of the researcher from artistic work to text, which in itself is the complex reality in the development stage, with problematized structure opened to external. 


\section{REFERENCES}

1. Григорьев В.П. Поэтика слова. М.: Наука, 1979. 342 с.

2. Лотман Ю.М. Внутри мыслящих миров. Москва: Языки русской культуры, 1996. 446 с.

3. Лотман Ю.М. Избранные статьи: В 3 т. Таллин: Александра, 1992, Т. 1.480 с.

4. Винокур Г.О. О языке художественной литературы. Москва: Высшая школа, 1991. 448 с.

5. Чередниченко И.В. Структурно-семиотический метод тартуской школы. Санкт-Петербург: Золотой век, 2001. 200 с.

6. Женетт Ж. Вымысел и слог: fictio el dictio / Пер с фp. И. Стаф // Женетт Ж.Фигуры: В 2 тт. Москва: Издательство им. Сабашниковых, 2003, Т. 2. С. 344-367.

7. Барт Р. Критика и истина // Зарубежная эстетика и теория литературы XIX - XX веков. Москва: Издательство МГУ, 1987. C. 349-386.

8. Барт Р. Введение в структурный анализ повествовательных текстов // Зарубежная эстетика и теория литературы XIX - XX веков. Москва: Издательство МГУ, 1987. С. 387-423.

9. Барт Р. Избранные работы. Семиотика и поэтика. Москва: Прогресс, 1989. 616 с.

\section{Information about the author:} Sventsitskaya E. M., Doctor of Philology, Professor, Department of Slavic Philology and Journalism, Academic and Scientific Institute of Philology and Journalism, V. I. Vernadsky Taurida National University 33, J. McCain str., Kyiv, 01042, Ukraine 